\title{
Tandem Repetition of the Origin of DNA Replication in Defective Polyoma Virus DNA's
}

\author{
WILLIAM R. FOLK AND BARBARA R. FISHEL \\ Department of Biological Chemistry. The University of Michigan. Ann Arbor, Michigan 48104
}

Accepted December 2, 1974

\begin{abstract}
The sequences derived from the polyoma virus genome which are tandemly repeated in a class of noninfectious covalently closed circular DNA's (Folk, W. R., and Wang, H. E., Virology 61, 140-155 (1974) have been identified. Specific fragments of polyoma DNA produced by cleavage with the $\mathrm{HpaIl}$ endonuclease have been purified, and the homology between each fragment and the noninfectious DNA's containing tandem repeats has been measured by DNA reassociation kinetics. The majority of the repeated sequences in the noninfectious DNA's are derived from the region of the genome containing the origin of DNA replication.
\end{abstract}

\section{INTRODUCTION}

We have previously characterized a population of noninfectious covalently closed circular DNA's derived from polyoma virus (Folk and Wang, 1974). The predominant DNA in the population was shown to contain three to four tandem repeats of a sequence comprising approximately $20 \%$ of the polyoma genome. Although the noninfectious DNA's are only $10-15 \%$ smaller than infectious polyoma DNA, major portions of the polyoma genome (including the site cleaved by the $E c o \mathrm{R}_{\mathrm{I}}$ endonuclease) have been deleted in the defective DNA's. A model indicating how DNA's containing tandem repetitions of a unique sequence might arise as a result of abortive replication of the polyoma genome was suggested; the model predicted that the repeated sequence would contain the site for the initiation of DNA replication.

In this report we extend the characterization of the sequences in the noninfectious DNA's by demonstrating that the predominant repeated sequence is derived from the region of the genome that includes the origin of DNA replication.

\section{METHODS}

(a). The following methods were performed as described previously (Folk and
Wang, 1974): (i) Growth of cells; (ii) preparation of virus; (iii) purification of viral DNA's; (iv) cleavage with $E c o \mathrm{R}_{\mathrm{I}}$ endonuclease; (v) measurement of DNA reassociation kinetics.

(b) Purification of HpaII endonuclease. Endonuclease HpaII was purified from Haemophilus parainfluenzae essentially as described by Sharp et al. (1973) with the following modifications: Frozen cells were disrupted by sonication; the extract was subjected to centrifugation at $100,000 \mathrm{~g}$ for $1 \mathrm{hr}$ and applied to a $2.6 \times 90-\mathrm{cm}$ column of Bio-Gel A-0.5m (200-400 mesh, Bio-Rad Labs). Peak fractions of HpaII activity (assayed with ${ }^{8} \mathrm{H}$-labeled SV40-DNA or ${ }^{3} \mathrm{H}$-labeled polyoma DNA) were pooled and further purified by phosphocellulose chromatography.

(c) Polyacrylamide-gel electrophoresis. DNA fragments produced by cleavage with site-specific endonucleases were separated by electrophoresis through $4 \%$ polyacrylamide gels ( $0.5 \%$ bis-acrylamide), as described by Danna et al. (1973), in an apparatus built by Hoefer Instruments, Inc., San Francisco, CA.

Following electrophoresis, analytical gels $(16 \times 30 \times 0.15 \mathrm{~cm})$ were dried onto Whatman $3 \mathrm{MM}$ paper under vacuum and autoradiographed with Kodak Blue Brand 447 
$\mathrm{X}$-ray film. Preparative gels $(16 \times 30 \times$ $0.30 \mathrm{~cm}$ ) were covered with Saran Wrap, autoradiographed, and the bands containing radioactive DNA fragments sliced out of the gel. Fragments were eluted from the minced gels by two successive elutions overnight with $10 \mathrm{mM}$ Tris-Cl, $1 \mathrm{mM}$ EDTA, pH 7.5, at $37^{\circ}$. Recovery was better than $70 \%$.

\section{RESULTS}

(a) Cleavage of Polyoma DNA's by HpaII Endonuclease

Infectious polyoma DNA is cleaved by the HpaII endonuclease into eight fragments (Griffin et al., 1974). We have confirmed this observation and have separated the fragments by electrophoresis through $4 \%$ acrylamide (Fig. 1). The good correspondence between the relative mobilities of the eight bands and their reported sizes provides strong evidence that they are the fragments ordered within the polyoma genome by Griffin et al. (1974) (Fig. 2). Confirmation that bands 1 and 2 are indeed fragments $A^{1}$ and $B$ is provided by the localization of a HindIII endonuclease site approximately $9 \%$ from one end of fragment $\mathrm{A}$ and another HindIII site approximately $3 \%$ from one end of fragment $B$ (Folk et al., 1975). Furthermore, band 2 contains the single site in the polyoma genome which is cleaved by the $E_{c o R_{1}}$ endonuclease (see below).

Infection of mouse cells with a stock of polyoma virus serially passed three times at low multiplicity (third passage virus; Folk and Wang, 1974) leads to the production of a population of closed circular polyoma DNA's, of which approximately $30 \%$ lack the site recognized by the Eco $\mathrm{R}_{\mathrm{I}}$ endonuclease (Folk and Wang, 1974). Those DNA's lacking the $E c o R_{I}$ site are not infectious and can be purified from the remainder of the polyoma DNA by virtue of their resistance to the $E c o R_{1}$ endonuclease.

${ }^{1}$ In accordance with the suggested nomenclature for fragments of DNA generated by restriction endonucleases (Smith and Nathans, 1974), the fragments HpaII 1-8 described by Griffin et al. (1974) are referred to as $\mathrm{HpaII} \mathrm{A}-\mathrm{H}$.
When the defective closed circular DNA's which are resistant to the $E_{\text {co }} \mathrm{R}_{\mathrm{I}}$ endonuclease (Folk and Wang, 1974) are digested with the HpaII endonuclease, a single major fragment with an electrophoretic mobility identical to that of $H p a I I-E$ is produced, as well as a heterogeneous mixture of larger products (Fig. 3 (1)). That the major fragment derived from the $E c o \mathrm{R}_{\mathrm{I}}$-resistant DNA is HpaII-E is supported by DNA reassociation kinetics discussed below.

Hpall digestion of the $E c o \mathrm{R}_{\mathrm{T}}$-sensitive DNA's derived from the same infection as the $E_{c o} R_{\mathrm{I}}$-resistant DNA's, generates eight major fragments, seven of which have mobilities identical to the mobilities of the

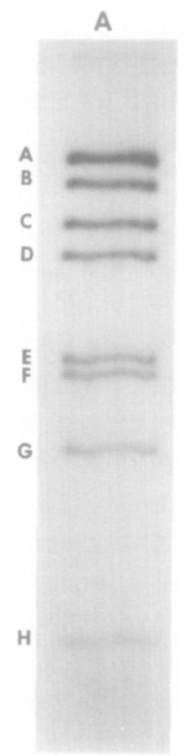

B

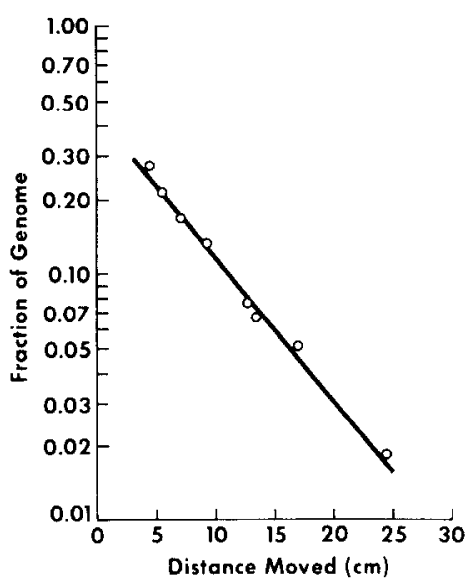

Fig. 1. (A) Autoradiogram of a preparative slab gel of polyoma ${ }^{32} \mathrm{P}$-labeled DNA digested with $H$ paII. Origin is at the top. Approximately $1.5 \times 10^{7} \mathrm{cpm}$ of ${ }^{32} \mathrm{P}$-labeled polyoma DNA $(30 \mu \mathrm{g})$ prepared from cells infected at low multiplicity (0.1-1 PFU/cell) with virus passaged once after plaque purification was digested for $4 \mathrm{hr}$ with excess $\mathrm{HpaII}$ endonuclease (the quantity of enzyme required for complete digestion was determined in a separate experiment) in $1 \mathrm{ml}$ of $10 \mathrm{~m} M$ Tris- $\mathrm{Cl}, 10 \mathrm{mM} \mathrm{MgCl}_{2}, 0.1 \mathrm{~m} M$ dithiothreitol, $6 \mathrm{mM} \mathrm{KCl}$ ( $\mathrm{pH} 7.3$ ). EDTA and sucrose were added to stop the reaction, and the solution was layered on top of a preparative slab gel. Electrophoresis was performed for $16 \mathrm{hr}$ at a constant current of $30 \mathrm{~mA}$. (B) The distance moved by each band in (A) is plotted against the fraction of the genome, as determined by Griffin et al. (1974). 


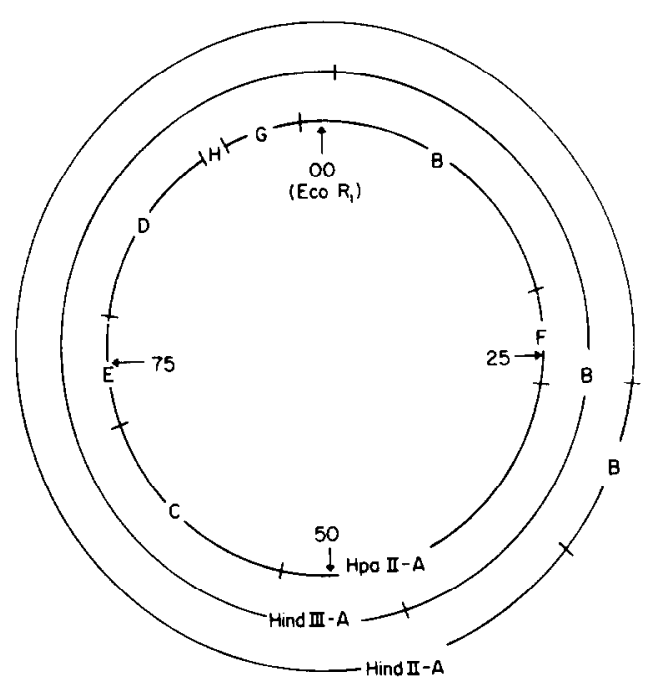

Fig. 2. Map of the polyoma genome, indicating sites cleaved by endonucleases $E c o R_{1}, H p a I I, H i n d I I I$ (Griffin et al., 1974) and HindII (Folk et al., 1975).

fragments produced from infectious, low multiplicity polyoma DNA (Fig. 3 (3)). Fragment HpaII-B has a slightly increased mobility, but this is to be expected, as this DNA was cleaved by the $E c o R_{1}$ endonuclease (so as to separate it from the $E c o R_{I^{-}}$ resistant DNA), and the $E c o R_{1}$ site is located very close to one end of fragment HpaII-B (Fig. 2).

The heterogeneous populations of fragments present in less than molar amounts in Fig. 3 represent sequences that have been reorganized within the polyoma genome, generating regions of DNA with a smaller or greater number of $\mathrm{Hpa \Pi l}$ sites than normally found (compare Fig. 1A with Fig. 3). Such reassortment appears to occur frequently when cells are infected at high multiplicity with polyoma virus (Folk and Wang, 1974; Robberson and Fried, 1974).

Fig. 3. Autoradiograms of closed circular DNA's from cells infected at high multiplicity following digestion with $H p a I I$ endonuclease and electrophoresis on polyacrylamide slab gels. (1) EcoR resistant DNA from cells infected at $20 \mathrm{PFU} /$ cell with third passage virus. (2) DNA derived by infection of cells at $20 \mathrm{PFU} /$ cell with virus from a single plaque passed once at low multiplicity (0.1 PFU/cell). (3) Eco $\mathrm{R}^{-}$ sensitive DNA from cells infected at $20 \mathrm{PFU} / \mathrm{cell}$ with
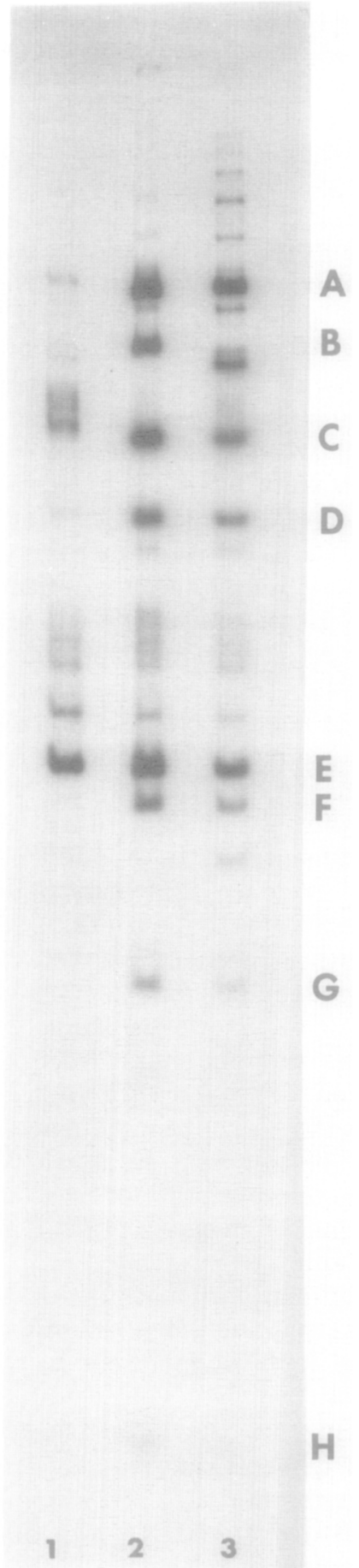

third passage virus. In each case, excess $H p a I l$ endonuclease was used to digest the DNA's in the buffer described in Fig. 1 in a volume of $0.05 \mathrm{ml}$. Under the same conditions, polyoma DNA from cells infected with the same virus as in (2) at low multiplicity (0.1-1 $\mathrm{PFU} /$ cell) yields the pattern of fragments in Fig. $1 \mathrm{~A}$. 
(b) Reassociation Between EcoR $R_{I}$-Resistant DNA and Isolated Fragments of Polyoma DNA

To determine which region of the polyoma genome is represented in the noninfectious closed circular DNA's with tandemly repeated sequences, the kinetics of reassociation of each of the HpaII fragments of polyoma ${ }^{32} \mathrm{P}$-labeled DNA was measured in the presence and absence of an excess of EcoR $\mathrm{R}_{1}$-resistant ${ }^{3} \mathrm{H}$-labeled DNA fragments. Sequence complementarity between the fragment and the $E c o \mathrm{R}_{\mathrm{I}}$-resistant DNA is indicated by an acceleration of the rate of reassociation of the ${ }^{32} \mathrm{P}$-labeled DNA fragment.

Figure 4 illustrates the effects of an excess of $E c o R_{\mathrm{I}}$-resistant ${ }^{3} \mathrm{H}$-labeled DNA upon the renaturation of each of the $H$ paII fragments. In most cases the reannealing of the ${ }^{32} \mathrm{P}$-labeled fragment is accelerated, indicating some degree of sequence homology with the EcoR $\mathrm{R}_{\mathrm{I}}$-resistant DNA. The small degree of complementarity exhibited with fragments $A, B, F$ and $G$ supports previous evidence that the population of $E_{c o R_{\mathrm{I}}}$-resistant DNA's contains some molecule with sequences derived from the majority of the polyoma genome (Folk and Wang, 1974). However, such molecules constitute only a small fraction of the population. The majority of the $E c o \mathrm{R}_{\mathrm{I}^{-}}$ resistant DNA's contain sequences complementary to fragment $\mathrm{E}$, as shown by its greatly accelerated rate of reassociation in the presence of an excess of $E c o R_{\mathrm{I}}$-resistant DNA (Table 1).

An approximate measure of the complementarity between $E c o R_{\mathrm{I}}$-resistant DNA and each fragment can be calculated from each fragment's accelerated rate of reannealing in the presence of $E c o R_{\mathrm{I}^{-}}$ resistant DNA (Table 1). These data indicate that the majority of the sequences in the $E c o R_{\mathrm{T}}$-resistant DNA are complementary to fragment $E$ and parts of fragments $\mathrm{C}$ and $\mathrm{D}$. The origin of DNA replication is located at the boundary of fragments $E$ and C (Griffin et al., 1974; Crawford et al., 1974; L. V. Crawford, personal communication).

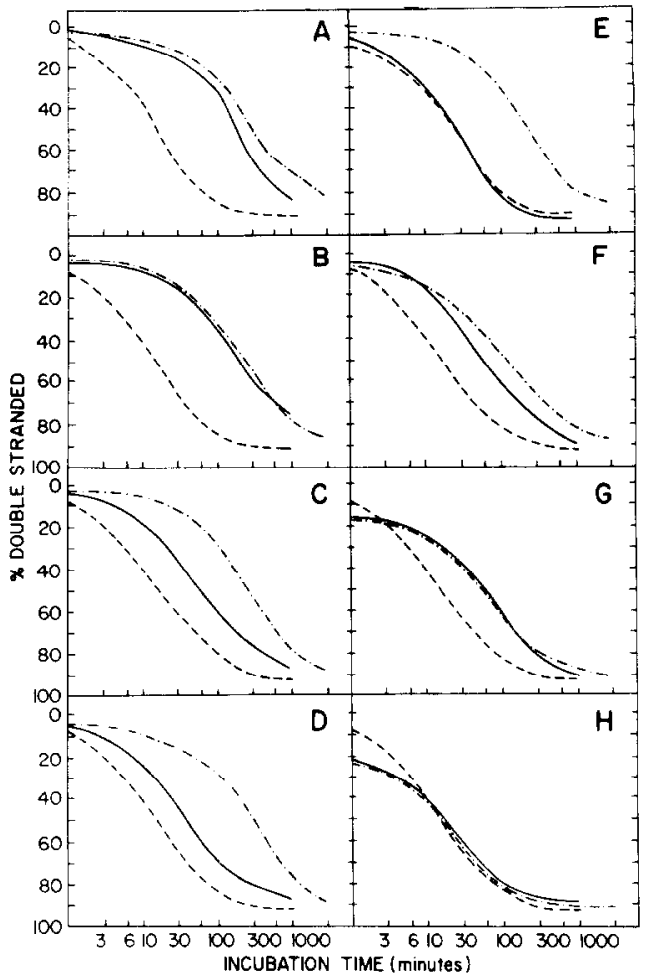

Fig. 4. Reassociation of "P-labeled DNA fragments alone or in the presence of excess $E c o R_{\mathrm{I}}$-resistant $\left[{ }^{3} \mathrm{H}\right]-\mathrm{DNA}$. Hpa II fragments of polyoma DNA purified from cells infected at low multiplicity (0.1-1 PFU/cell) were purified by electrophoresis through acrylamide slab gels and eluted as described in Methods. Fragments A, B, C and D were sonicated prior to use (Folk and Wang, 1974) to reduce their size to approximately 500 base pairs. EcoR $\mathrm{R}_{1}$-resistant ${ }^{3} \mathrm{H}$ labeled DNA was purified from cells infected at high multiplicity with third passage virus (Folk and Wang, 1974) and sonicated before use. In each instance, between 300 and $800 \mathrm{cpm}$ of ${ }^{32}$ P-labeled DNA fragment $\left(2 \times 10^{5}-8 \times 10^{5} \mathrm{cpm} / \mu \mathrm{g}\right.$ in separate experiments) was denatured alone or together with $1,000-2,000$ $\mathrm{cpm}$ of ${ }^{3} \mathrm{H}$-labeled DNA $\left(10^{4}-4 \times 10^{4} \mathrm{cpm} / \mu \mathrm{g}\right.$ in separate experiments) and allowed to reassociate at $65^{\circ}$ in $0.12 M$ phosphate buffer, $\mathrm{pH} 6.8$. Aliquots were removed at intervals, and single-stranded DNA was separated from duplex DNA on hydroxyapatite columns at $60^{\circ}$. No correction was made for duplex DNA at $T_{0}$ (usually less than $5 \%$ ) or for less than $100 \%$ reassociation. Actual values for the DNA concentrations employed, and the measured values of the $C_{0} t_{t_{2}}$ for each DNA are given in Table 1. (- - - ), Reassociation of ${ }^{32} \mathrm{P}$-labeled fragment alone; (-), reassociation of ${ }^{32} \mathrm{P}$-labeled fragment mixed with ${ }^{3} \mathrm{H}$-labeled DNA; (...), reassociation of ${ }^{3} \mathrm{H}$-labeled DNA mixed with ${ }^{32}$ P-labeled fragment. Letters at top of each graph refer to HpaII fragments used as ${ }^{32} \mathrm{P}$-labeled DNA. 
TABLE 1

Homology Between $E c o R_{\text {I }}$ Resistant DNA and Polyoma hpaII Fragments

\begin{tabular}{|c|c|c|c|c|c|c|}
\hline \multirow[t]{2}{*}{ Fragment } & \multicolumn{2}{|c|}{ DNA concentration ${ }^{\alpha}$} & \multicolumn{2}{|c|}{$T_{k_{2}}^{o}$} & \multirow{2}{*}{$\begin{array}{l}\text { Accel- } \\
\text { eration }\end{array}$} & \multirow{2}{*}{$\begin{array}{c}\text { Relative } \\
\text { homology }^{d}\end{array}$} \\
\hline & $\begin{array}{c}{ }^{32} \mathrm{P}- \\
\text { labeled } \\
\text { fragment }\end{array}$ & $\begin{array}{c}{ }^{3} \mathrm{H}- \\
\text { labeled } \\
\text { EcoR } \\
\text { resistant }\end{array}$ & $\begin{array}{c}{ }^{32} \mathrm{P} . \\
\text { labeled } \\
\text { fragment }\end{array}$ & $\begin{array}{c}{ }^{3} \mathrm{H}- \\
\text { labeled } \\
E c o R_{\mathrm{I}} \\
\text { resistant }\end{array}$ & & \\
\hline A & .31 & & 260 & & & \\
\hline $\mathrm{A}+\left[{ }^{3} \mathrm{H}\right] E c o \mathrm{R}_{1}$-resistant & $\begin{array}{r}.29 \\
27\end{array}$ & 5.7 & 200 & 16 & 1.3 & $.027(.094)^{e}$ \\
\hline $\begin{array}{l}\mathrm{B} \\
\mathrm{B}+\left[\mathrm{H}^{3}\right] E c o \mathrm{R}_{\mathrm{I}} \text {-resistant }\end{array}$ & $\begin{array}{l}.27 \\
.27\end{array}$ & 5.8 & $\begin{array}{l}250 \\
190\end{array}$ & 15 & 1.3 & $.015(.076)$ \\
\hline $\mathrm{C}$ & .25 & & 260 & & & \\
\hline $\begin{array}{l}\mathrm{C}+\left[\mathrm{H}^{3}\right] E \operatorname{co} \mathrm{R}_{\mathrm{I}} \text {-resistant } \\
\mathrm{D}\end{array}$ & $\begin{array}{l}.25 \\
.16\end{array}$ & 6.2 & $\begin{array}{r}58 \\
260\end{array}$ & 17 & 4.5 & $.136(.112)$ \\
\hline $\begin{array}{l}\mathrm{D}+\left[{ }^{3} \mathrm{H}\right] E \operatorname{Eco} \mathrm{R}_{\mathrm{r}} \text {-resistant } \\
\mathrm{E}\end{array}$ & $\begin{array}{l}.15 \\
.20\end{array}$ & 6.7 & $\begin{array}{r}38 \\
260\end{array}$ & 15 & 6.8 & $.153(.171)$ \\
\hline $\begin{array}{l}\mathrm{E}+\left[{ }^{3} \mathrm{H}\right] E c o \mathrm{R}_{\mathrm{I}} \text {-resistant } \\
\mathrm{F}\end{array}$ & $\begin{array}{l}.20 \\
.29\end{array}$ & 5.7 & $\begin{array}{r}16 \\
105\end{array}$ & 16 & 16.3 & $.470(.382)$ \\
\hline $\begin{array}{l}\mathrm{F}+\left[{ }^{3} \mathrm{H}\right] E c o \mathrm{R}_{\mathrm{I}} \text {-resistant } \\
\mathrm{G}\end{array}$ & $\begin{array}{l}.30 \\
.34\end{array}$ & 6.7 & $\begin{array}{l}80 \\
55\end{array}$ & 16 & 1.3 & $.110(.135)$ \\
\hline $\begin{array}{l}\mathrm{G}+\left[{ }^{3} \mathrm{H}\right] E \cos \mathrm{R}_{\mathrm{I}}-\text { resistant } \\
\mathrm{H}\end{array}$ & $\begin{array}{l}.32 \\
.21\end{array}$ & 6.2 & $\begin{array}{l}50 \\
17\end{array}$ & 17 & 1.1 & $.109(.043)$ \\
\hline $\mathrm{H}+\left[{ }^{3} \mathrm{H} \mid E c o \mathrm{R}_{\mathrm{I}}\right.$-resistant & .22 & 6.8 & 16 & 15 & 1.1 & Not determined \\
\hline
\end{tabular}

${ }^{a} A_{280} \times 10^{-3} / \mathrm{ml}$. Data refer to those shown in Fig. 4 .

${ }^{\circ}$ Time in minutes required for $50 \%$ of the DNA to become duplex, as determined by hydroxyapatite fractionation.

${ }^{c}$ Relative acceleration of reassociation of fragment ${ }^{32} \mathrm{P}$-labeled DNA by ${ }^{3} \mathrm{H}$-labeled DNA. (Ratio of $T_{1,8}$ alone to $T_{1 / 2}$ in presence of ${ }^{3} \mathrm{H}$-labeled DNA).

${ }^{d}$ Relative homology, as defined by the relationship $\left[\left(C_{0} T_{45}(a) / C_{0} T_{\psi_{2}}(b)\right) \times A_{260}(a)-A_{260}(b)\right] / A_{260}(c)-A_{260}$ (b), where $a=$ value for ${ }^{32} \mathrm{P}$-labeled DNA fragment incubated alone, $b=$ value for ${ }^{32} \mathrm{P}$-labeled DNA fragment

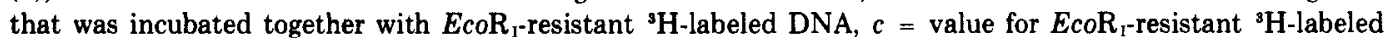
DNA. This approximates the quantity of DNA sequences homologous to each fragment that is contributed by the ${ }^{3} \mathrm{H}$-labeled DNA (the numerator) divided by the total amount of DNA sequence contributed by the Eco $\mathrm{R}_{1}$-resistant. DNA present in the reassociation mix (the denominator).

${ }^{e}$ Values in parentheses refer to data obtained in a separate experiment in which another set of ${ }^{32} \mathrm{P}$-labeled DNA fragments (from an independent preparation of polyoma DNA) and another preparation of ${ }^{3} \mathrm{H}$-labeled DNA were analyzed in an identical manner. Results from the two experiments were qualitatively the same. Small quantitative differences probably reflect the heterogeneity of two separate preparations of $E$ co $R_{1}$-resistant DNA prepared with different cells at slightly different multiplicities. In each instance, ${ }^{32} \mathrm{P}$-labeled DNA fragments were prepared by digesting polyoma DNA from 3T6 cells infected at low multiplicity (less than 1 PFU/cell) with virus from a single plaque passaged once at low multiplicity; ${ }^{3} \mathrm{H}$-labeled DNA was prepared by purifying the $E c o \mathbf{R}_{\mathrm{I}}$-resistant covalently closed circular DNA from cells infected at 10-20 PFU/cell with third passage virus (Folk and Wang, 1974).

\section{DISCUSSION}

The observation that a unique sequence predominates in the population of noninfectious, $E c o R_{\mathrm{I}}$ endonuclease-resistant DNA's agrees with our interpretation of the previously reported reassociation data (Folk and Wang, 1974). That the repeated sequence contains the origin of replication is in accord with the model by which tandem, repeating sequences of DNA might be generated (Folk and Wang, 1974). Several other instances have been reported in which mistakes during replication have been suggested as causing reassortment of sequences within the closed circular DNA's of polyoma virus and of $\lambda d v$ (Robberson and Fried, 1974; Chow et al., 1974). However, proof that such reassorted genomes are generated by replication mistakes will be difficult to obtain.

Recently, reassortment and repetition of 
sequences within circular SV40 and SV40like viruses have been reported (Brockman et al., 1974; Martin et al., 1973; Fareed et al., 1974; Khoury et al., 1974). Two specific recombinational events in addition to a triplication have been proposed to account for the observed rearrangements in the SV40-like DNA's. The evidence presented here and in a previous report (Folk and Wang, 1974) indicate, however, that the DNA's with repeated polyoma sequences which we have characterized are not likely to contain transpositions or inversions of sequences, and are consequently considerably simpler than the defective SV40-like DNA's. Independent characterization of a wider variety of defective polyoma DNAs has recently been reported by Fried et al. (1975).

The noninfectious polyoma DNA's with tandemly repeated sequences appear to lack most of the genome except that part which includes the origin of replication. Beside lacking the site cleaved by the $E_{c o R_{I}}$ endonuclease (Folk and Wang, 1974), they are resistant to the HindII and HindIII endonucleases, each of which cleaves polyoma DNA twice (Fig. 2; our unpublished results). The deleted region of the genome codes for the RNA's synthesized late in infection which contain the information determining viral structural proteins (Kamen et al., 1975).

The infectious polyoma DNA's that accompany the $E c o \mathrm{R}_{\mathrm{I}}$-resistant DNA's in the infected cell probably provide genetic information required for the production of enzymes necessary to replicate the closed circular DNA's and for structural proteins which encapsidate the DNA's and allow them to pass from cell to cell. The pattern of fragments produced after digestion of the infectious $E$ co $\mathrm{R}_{\mathrm{r}}$-sensitive DNA withHpaII endonuclease is very much the same as that observed with "low multiplicity" polyoma DNA. However, in the EcorR ${ }^{-}$ sensitive DNA's the molar yield of fragment $\mathrm{E}$ relative to the other fragments is substantially increased, suggesting that serial repetition of the origin of replication may have occurred even in molecules containing the $E c o R_{t}$ site. Such rearrange- ments appear to occur rapidly when cells are infected with polyoma virus at high multiplicity (compare the intensities of bands in Fig. 1, low multiplicity infection, with Fig. 3 (2), high multiplicity infection).

\section{ACKNOWLEDGMENTS}

This work was supported by Grant No. CA-13978-02 from the National Institutes of Health and, in part, by a grant from The University of Michigan Cancer Research Institute.

\section{REFERENCES}

Brockman, W. W., Lee, T. N. H., and Nathans, D. (1974). The evolution of new species of viral DNA during serial passage of SV-40 at high multiplicity. Virology 54, 384-397.

Chow, L. T., Davidson, N., and Berg, D. (1974). Electron microscope study of the structures of $\lambda \mathrm{dv}$ DNAs. J. Mol. Biol. 86, 69-89.

Crawford, L. V., Robbins, A. K., and Nicklin, P. M. (1974). Location of the origin and terminus of replication in polyoma virus DNA. J. Gen. Virol. 25, 133-142.

Danna, K. J., Sack, G. H., and Nathans, D. (1973). Studies of SV-40 DNA. VII: A cleavage map of the SV-40 genome. J. Mol. Biol. 78, 377-389.

Fareed, G. C., Byrne, J. C., and Martin, M. A. (1974). Triplication of unique genetic segment in a SV-40-like virus of human origin and evolution of new viral genomes. J. Mol. Biol. 98, 275-288.

Folk, W. R., Fishel, B. R., and Anderson, D. M. (1975). Sites in the polyoma genome cleaved by restriction endonuclease hindII. Virolngy (In Press).

Folk, W. R., and WANG, H. E. (1974). Closed circular DNAs with tandem repeats of a sequence from polyoma virus. Virology 61, 140-155.

Fried, A. M. C., Griffin, B. E., Lund, E., and RobBerson, D. L. (1975). Polyoma virus-a study of wild type, mutant and defective DNAs. Cold Spring Harbor Symp. Quant. Biol. (In Press).

Griffin, B. E., Fried, A. M. C., and Cowie, A. (1974). Polyoma DNA: A physical map. Proc. Nat. Acad. Sci. USA, 71, 2077-2081.

Kamen, R., Lindstrom, D. M., Shore, H., and OLd, R. W. (1975) Virus-specific RNA in cells productively infected or transformed by polyoma virus. Cold Spring Harbor Symp. Quant. Biol. (In Press).

Khoury, G., Fareed, G. C., Berry, K., Martin, M. R., Lee, T. N. H., and Nathans, D. (1974). Characterization of a rearrangement in viral DNA: Mapping of the circular SV-40-like DNA containing a Triplication of a specific one-third of the viral genome. J. Mol. Biol, 87, 289-301.

Martin, M. A., Gelb, L. D., Fareed, G. C., and 
Milstien, J. B. (1973). Reassortment of SV-40 DNA during serial undiluted passage. J. Virol. 12, 748-757.

Robberson, D. L., and Fried, A. M. C. (1974). Sequence arrangements in clonal isolates of polyoma defective DNA. Proc. Nat. Acad. Sci. USA, 71, 3497-3501.

Sharp, P. A., Sugden, B., and Sambrook, J. (1973).
Detection of two restriction endonuclease activities in $I I$. parainfluenzae using analytical agaroseethidium bromide electrophoresis. Biochemistry 12, 3055-3061.

SMith, H. O., and Nathans, D. (1973). A suggested nomenclature for bacterial host modification and restriction systems and their enzymes. J. Mol. Biol. 81, 419-423. 